\title{
Effects of animal selection on milk composition and processability
}

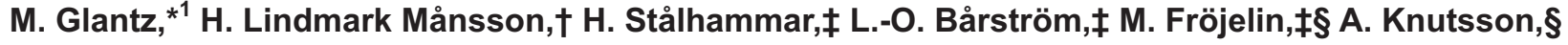 \\ C. Teluk, ${ }^{*}$ and M. Paulsson* \\ *Department of Food Technology, Engineering and Nutrition, Lund University, PO Box 124, SE-221 00 Lund, Sweden \\ †Swedish Dairy Association, Ideon Science Park, SE-223 70 Lund, Sweden \\ ¥VikingGenetics, PO Box 64, SE-532 21 Skara, Sweden \\ §Nötcenter Viken, Vikens Egendom, SE-521 91 Falköping, Sweden
}

\section{ABSTRACT}

One goal of animal breeding is to increase the economic output through increased production, improved milk quality, and cow health. The objective of this study was to evaluate genetic progress in relation to milk composition, processability, and yield as a correlated response to selection for the Swedish breeding objective. Dairy cows with high genetic merit, classified as elite dairy cows, of the Swedish Red and Swedish Holstein breeds were used. Milk samples were collected on the farm level in winter and summer from a research herd at Nötcenter Viken, a bovine research farm in Sweden. Comparisons were made with milk from a Swedish Red herd, a Swedish Holstein herd, and a Swedish dairy processor in the same geographical area. Protein, lipid, and carbohydrate profiles as well as minerals were analyzed, and technological properties, including rennet-induced gelation characteristics, lipid oxidation, total antioxidant capacity, and fat globule size, were determined. Higher yields were found for elite cows for components of the protein, lipid, and carbohydrate profiles as well as for minerals, implying genetic progress in relation to milk yield; however, the content of some milk components (e.g., lipid and whey protein contents) had decreased on average. Milk from the elite cows had good gelation characteristics, but was more susceptible to lipid autooxidation and had a lower total antioxidant capacity. These results demonstrate that milk composition and processing characteristics could be used to adjust breeding practices to optimize the quality and stability of milk and dairy products.

Key words: elite dairy cow, milk composition, milk processability, milk yield

\section{INTRODUCTION}

During the last decade, genetic research has been able to reveal several important aspects of milk com-

Received July 1, 2008.

Accepted May 5, 2009

${ }^{1}$ Corresponding author: maria.glantz@food.lth.se position related to dairy cow genetics. Additive genetic effects have been shown to have great effects on milk production traits, with high heritability for lipid (0.52), protein (0.60), and lactose contents (0.64) and moderate heritability for yields of milk (0.44), lipids (0.37), proteins (0.34), and lactose (0.47), thus indicating that milk composition can be changed by selective breeding (Stoop et al., 2007, 2008). On the other hand, the effect of herd is larger for urea content (0.58) and freezing point (0.38) than genetic effects, implying the importance of herd practices for optimizing these traits (Stoop et al., 2006, 2007). Furthermore, the large genetic gain in production traits proves that this has also been achieved in practical breeding work (VikingGenetics, 2008). Although the technological properties of milk that affect its processing into other dairy products are important in the dairy industry, genetic parameters for milk processability are still limited.

Over the years, many studies have been performed on the composition of milk, but only a few milk components are usually investigated with regard to breed, feed, or seasonal changes, such as the influence of these parameters on fatty acid (FA) composition and protein profile (Wedholm et al., 2006a; Soyeurt and Gengler, 2008). A limited number of investigations have determined several components of dairy milk (Pinto et al., 1998; Lindmark Månsson et al., 2003) and processed milk (Smit et al., 1998; O'Brien et al., 1999a; O'Brien et al., 1999b,c). The composition of the milk determines the technological properties and processability of several milk-based products, including cheese, butter, yogurt, and other acid milk products. Recent studies regarding the relationship of the genetic polymorphism of milk proteins and milk clotting properties (Wedholm et al., 2006b; Hallén et al., 2007) with cheese yield (Wedholm et al., 2006b), have indicated that genetic variants of milk proteins affect cheese-making properties. However, other factors, including the calcium content, the ratio of $\mathrm{CN}$ to whey proteins, $\mathrm{pH}$, and the fat globule size, have also been shown to influence these properties and to play an important role in the manufacture of dairy products (Amenu and Deeth, 2007). Another impor- 
tant technological property is the oxidative stability of milk, in which milk antioxidants play important roles in preventing lipid peroxidation and maintaining milk quality (Lindmark Månsson and Åkesson, 2000).

Animal breeding is used to optimize different factors and traits, such as improving milk quality and cow health, to increase the economic output. In Sweden, today's breeding objective is to produce a healthy cow with greater milk and protein yields, as well as greater protein and lipid contents; better female fertility; and excellent calving traits, together with a more functional conformation (VikingGenetics, 2006). An integrated part of the Swedish breeding occurs at the research farm Nötcenter Viken (NCV) in Falköping, northeast of Gothenburg, Sweden. This farm has a unique nucleus breeding herd producing a large number of bull dams. The herd consists of the 2 most common dairy cow breeds in Sweden, the Swedish Red (SR) and the Swedish Holstein ( $\mathbf{S H})$. At the time of this study, the yields of milk, lipids, and proteins per cow at NCV were 31, 19, and $35 \%$ higher, respectively, than the average yield per cow for farms in Sweden. In 2005, the yields of milk, lipids, and proteins were 31, 37, and 32\% higher, respectively, in Sweden than the average yield in Europe (International Committee for Animal Recording, 2008). Thus, because of their high genetic merit, the cows at the NCV reflect the expected genetic merit of the future Swedish cow population and can therefore be classified as elite cows.

The aim of the present investigation was to study genetic progress in relation to milk composition, processability, and milk yield as a correlated response to selection for the Swedish breeding objective of elite cows of the 2 Swedish dairy cow breeds SR and SH. More specifically, milk protein, lipid, and carbohydrate profiles, as well as minerals, were analyzed, and technological properties for milk processing, including rennetinduced gelation characteristics, lipid oxidation, total antioxidant capacity (TAC), and fat globule size, were determined in milk from the elite dairy cows. Using elite cows together with the large number of parameters studied will provide unique information on the effects of animal selection on both milk composition and processability, as well as on opportunities to optimize breeding practices.

\section{MATERIALS AND METHODS}

\section{Milk Collection}

Milk samples were collected in the winter and summer of 2007 from 3 herds in the same geographical area: the research herd at the NCV (research herd), including both SR and SH cows, an SR herd at another farm (SR herd), and an $\mathrm{SH}$ herd from a third farm ( $\mathrm{SH}$ herd). The SR and SH herds were selected to be comparable with the cows at the NCV regarding the feeding system and geographical location. All cows in the study were healthy and were milked either twice a day (the SR and SH herds) or 3 times a day (the research herd). Samples were collected twice, 1 wk apart, in February and August 2007 from the research herd at NCV (304 and 300 cows on the 2 occasions in February, and 293 and 297 cows on the 2 occasions in August), from the SR herd (53 and 50 cows in February, and 51 and 52 cows in August), and from the $\mathrm{SH}$ herd (108 and 110 cows in February, and 104 and 104 cows in $\mathrm{Au}-$ gust). In addition, milk samples were collected on the 2 occasions in August 2007 from 145 and 147 SR cows (research herd SR), and 148 and $150 \mathrm{SH}$ cows (research herd $\mathrm{SH}$ ) at the research farm NCV. Representative volumes in proportion to the milk yield of each cow were sampled and carefully mixed before a sample of approximately $5 \mathrm{~L}$ was taken for each breed. Milk yields were recorded for all the herds on each sampling occasion. For comparison, bulk milk from the local dairy company, representing the whole collection area, was used as a reference (reference milk) and was collected directly from the tank on the same days as the other milk samples. The dairy receives $102 \mathrm{t}$ of milk per year (Falköpings Mejeri, 2007), and the proportions of different breeds in the collection area are $51 \% \mathrm{SH}$ and 49\% SR (Swedish Dairy Association, 2008).

After collection, the samples were cooled directly, transported to Lund University, and stored at $4^{\circ} \mathrm{C}$ overnight. The following day, the $\mathrm{pH}$ was measured and the samples were thoroughly mixed, subsampled, and either analyzed directly or stored at $-20^{\circ} \mathrm{C}$ until later analysis. Yields per cow per sampling day were calculated by multiplying each percentage by the milk yield.

\section{Milk Composition}

To obtain a detailed understanding of the complex relationships among milk composition traits, the milk was extensively analyzed by several methods to determine the amounts and proportions of the components of interest. Fresh milk samples were analyzed for contents of total protein, lipids, lactose, and urea and for the freezing point by using an infrared technique (Combifoss 5000, Foss Analytical A/S, Hillerød, Denmark), and for somatic cells by using flow cytometry (Combifoss 5000) at a certified dairy analysis laboratory (Eurofins Steins Laboratory, Jönköping, Sweden). The contents of total nitrogen, protein, $\mathrm{CN}$, whey proteins, soluble nitrogen, and NPN were analyzed by using the Kjeldahl method (IDF 20-2:2001, IDF 29-1:2004, IDF 20-4:2001). The 
content of lipids was analyzed by using the Röse-Gottlieb gravimetric method (IDF 1D:1996). The protein and lipid contents were determined with both reference methods (IDF 20-2:2001, IDF 1D:1996) and by using an infrared technique (Combifoss 5000). No differences were observed among the different methods, and values from the reference methods are reported. The content of FFA was analyzed in samples preserved in test tubes with an organic solution directly after sampling (Lindqvist et al., 1975) by using a colorimetric technique (Technicon Auto-Analyzer System II, Colorimetric Flowcell Recorder, Pulse Instrumentation Ltd., Saskatoon, Saskatchewan, Canada), and the FA composition was determined by gas chromatography methods (Ce 1-62, AOCS, 1997; and Ce 1f-96, AOCS, 2002) using an instrument from Agilent Technologies Inc. (GC-FID 6890, Agilent Technologies Inc., Santa Clara, CA). The contents of calcium, phosphorus, potassium, magnesium, and zinc were determined by inductively coupled plasma mass spectroscopy (DS13805:2002-ICP-OES). The above-mentioned milk components were analyzed at another certified dairy analysis laboratory (Eurofins Steins Laboratory, Holstebro, Denmark). Lactic acid was analyzed with an enzymatic kit (EnzyPlus EZA891+, BioControl Systems Inc., Bellevue, WA), and the absorbance was determined at $340 \mathrm{~nm}$ with a spectrophotometer (Hitachi Model U-1500 UV/Vis, Hitachi Instruments Inc., San Jose, CA). The CN number was calculated as the ratio of $\mathrm{CN}$ to total protein. All samples were analyzed at least in duplicate.

\section{Technological Processing Properties}

Rheological Measurements. Fresh milk samples were defatted by centrifugation at 2,000 $\times g$ for $30 \mathrm{~min}$ and subsequent removal of the fat layer to reduce the number of variables influencing gel strength and gelation time. Ten milliliters of defatted milk was preheated to $32^{\circ} \mathrm{C}$ in a water bath, followed by the addition of chymosin $(0.90 \mathrm{~mL} / \mathrm{L}$ of Chy-Max Plus, 200 international milk clotting units/mL, Chr. Hansen A/S, Hørsholm, Denmark) and gentle stirring. The solution was immediately poured into the concentric cylinder cell (CC15) with the bob and cup of a Stresstech rheometer (ReoLogica Instruments AB, Lund, Sweden). Rennetinduced gelation was carried out with low-amplitude oscillation measurements, with controlled strain at 0.01 and $1 \mathrm{~Hz}$. The temperature was held constant at $32^{\circ} \mathrm{C}$ and measurements were carried out for $30 \mathrm{~min}$. Gel strength, measured as the gel elasticity (elastic or storage modulus; $\mathrm{G}^{\prime}$ ) of the developing gel, was plotted against time; the addition of chymosin corresponded to time zero. The gelation time, defined as $\mathrm{G}^{\prime \prime}=\mathrm{G}^{\prime}$ (i.e., $\tan \delta=45^{\circ}$ ), was measured; $\mathrm{G}^{\prime \prime}$ is the viscous or loss modulus, defined as $\mathrm{G}^{\prime \prime}=\sigma_{0} / \gamma_{0} \cdot \sin \delta\left(\sigma_{0}=\right.$ maximum stress; $\gamma_{0}=$ maximum shear strain; $\delta=$ phase angle, phase difference between the strain and stress). The loss tangent is defined as $\tan \delta=\mathrm{G}^{\prime \prime} / \mathrm{G}^{\prime}$. Rheological measurements were performed at least in duplicate for each sample.

Fat Globule Size Measurements. The volumeweighted droplet diameter, $\mathrm{d}(4,3)$, of the fat globules was determined in fresh milk samples at $20^{\circ} \mathrm{C}$ by using light diffraction (Coulter LS 130, Beckman Coulter, High Wycombe, UK). The refractive index of milk fat at $20^{\circ} \mathrm{C}(\mathrm{n}=1.46$; Walstra and Jenness, 1984) was used in the optical model. Duplicate measurements were made on each sample.

Oxidation Measurements. The method described by Östdal et al. (2000) was used to measure lipid hydroperoxides in the primary phase of lipid oxidation by a colorimetric reaction. Milk samples were prepared by mixing $5 \mathrm{~mL}$ of milk and $5 \mathrm{~mL}$ of methanol (Merck KGaA, Darmstadt, Germany), after which $10 \mathrm{~mL}$ of chloroform (Merck KGaA) was added and the mixture shaken. Samples were stored for $24 \mathrm{~h}$ before $1 \mathrm{~mL}$ of the chloroform phase (lower phase) was transferred to a test tube. Measurements were performed at least in duplicate on each sample. To construct a calibration curve of $\mathrm{Fe}^{3+}$ concentration versus absorbance, a modification of the method described by Shantha and Decker (1994) was used. A standard solution of iron(III) chloride (2 $\mathrm{g} / \mathrm{L})$ was prepared. One gram of iron powder was dissolved in $50 \mathrm{~mL}$ of $10 M$ hydrochloric acid, and $2 \mathrm{~mL}$ of $30 \%$ hydrogen peroxide solution was added. Excess hydrogen peroxide was removed by boiling the solution for 5 min before cooling to room temperature. The solution was diluted in water to give standard samples containing $1,5,10,20$, and $40 \mu \mathrm{g}$ of $\mathrm{Fe}(\mathrm{III}) / \mathrm{mL}$, which were analyzed by the method described by Östdal et al. (2000). The peroxide value $(\mathrm{mEq} / \mathrm{kg})$ was calculated according to Shantha and Decker (1994).

The thiobarbituric acid (TBA) reaction described by King (1962) was used to measure a secondary lipid oxidation product, malonaldehyde. Measurements were performed on each sample at least in duplicate. The concentration $(M / \mathrm{kg})$ of the complex formed between malonaldehyde and TBA, referred to as the TBA value, was calculated using the extinction coefficient of the complex $\left(1.56 \cdot 10^{5} \mathrm{M} / \mathrm{cm}\right.$ at $532 \mathrm{~nm}$; Nourooz-Zadeh et al., 1995).

$\boldsymbol{T A C}$. The TAC was measured in milk and whey as described by Chen et al. (2003). Whey was prepared by preheating $50 \mathrm{~mL}$ of defatted milk to $31^{\circ} \mathrm{C}$ in a water bath, followed by the addition of $0.06 \%$ (vol/ vol) rennet (75/25 chymosin/pepsin, $180 \pm 10$ international milk clotting units/mL, Kemikalia AB, Skurup, Sweden) during gentle stirring. After approximately 30 
min, after curd formation, the mixture was filtered. A calibration curve was obtained using the water-soluble vitamin $\mathrm{E}$ analog Trolox by replacing the samples with $2.5,5,10$, and $20 \mu \mathrm{L}$ of $250 \mu M$ Trolox (Sigma-Aldrich, Steinheim, Germany) diluted in $0.1 M$ potassium phosphate buffer at $\mathrm{pH}$ 6.7. Measurements were performed at least in duplicate on each sample.

\section{Statistical Analyses}

Statistical ANOVA was performed to calculate mean values and standard deviations for the various milk components, yields, and technological properties. Twosample $t$-tests were performed to evaluate herd differences and seasonal variations based on winter and summer milk samples. The level of significance was set at $P$ $<0.05$. The general linear model was used to exclude differences attributable to sampling day and analytical replicates. The statistical model used contained the fixed effects of herd, sampling day, and analytical replicates. All statistical evaluations were performed using Minitab version 14 (Minitab Ltd., Coventry, UK).

\section{RESULTS AND DISCUSSION}

\section{Comparison of Samples}

Milk composition varies, for example, according to breed, feed, and season, but also between individual cows compared with milk at the farm and dairy levels. The results of our study are based on farm milk and related to dairy milk collected from the corresponding geographical area. This comparison was chosen based on the assumption that, in the future, the milk quality originating from the NCV could be the average milk composition in the area collected by the dairy company. Comparing milk from the NCV with the SR and $\mathrm{SH}$ herds could result in uncertainties because of effects on the farm level, such as performance of the cows and their genetic background. It is therefore difficult to compare our results with those of other studies, which are usually done on individual cows and on the influence of feeding on the milk composition.

The cows in the research herd were milked 3 times a day, whereas the SR and SH herds were milked only twice a day. A higher milking frequency has been shown to increase milk yield but decrease content of milk components (Klei et al., 1997; Österman et al., 2005). In our study, the effects of animal selection on milk composition and processability were evaluated, focusing on the genetic progress of elite dairy cows. This also includes an increase in milk yield, which will result in a need for more frequent milking. At the NCV, when changing from 2 to 3 milkings a day, the impact on yields of milk, proteins, and lipids was studied (unpublished data) and the increase in milk yield was shown to be approximately $9 \%$ for both SR and SH. Corresponding results for yield of the sum of proteins and lipids were $7 \%$ for SR and 5\% for SH. In our study, the difference in milk yield between the research herd SR and the SR herd was $35 \%$ and the yield of the sum of proteins and lipids was $31 \%$, whereas the values for the research herd $\mathrm{SH}$ and the $\mathrm{SH}$ herd were 24 and $18 \%$, respectively (Table 1). This shows that the main differences in milk yield and yield of the sum of proteins and lipids were explained, to a minor degree, by the milking frequency. Thus, the milking frequency was not taken into account when the results of the contents of milk components were evaluated.

\section{Genetic Progress in Relation to Milk Composition}

Protein Profile. A comparison of milk from the research herd and the reference milk showed seasonal variations and differences in the contents of protein, $\mathrm{CN}$, and whey proteins. The protein content of the research herd milk was higher in winter, $3.52 \mathrm{~g} / 100$ g (SD 0.02, $P=0.002$ ), and lower in summer, 3.26 $\mathrm{g} / 100 \mathrm{~g}$ (SD 0.06, $P=0.030$ ) than the protein content of the reference milk. Furthermore, seasonal variation was found for research herd milk $(P=0.004)$ that was not seen for reference milk (Tables 1, 2, and 3). A lower protein content has negative effects on cheese yield, but the yield is also affected by the CN content in the protein fraction. Differences in CN content were, however, not observed between research herd milk and reference milk in winter or summer samples. The $\mathrm{CN}$ number showed no difference in winter milk samples, whereas it was higher in research herd summer milk $(P=0.015)$ than in reference summer milk, thus indicating good gelation properties. The content of whey proteins was lower in research herd summer milk $(P=0.009)$ than in reference summer milk, and the research herd showed no seasonal variation in either $\mathrm{CN}$ or whey proteins. Both the protein and $\mathrm{CN}$ contents in the reference milk were in accordance with average values found previously for dairy milk in Sweden (Lindmark Månsson et al., 2003), whereas the whey protein content was lower in the reference milk. The study performed by Lindmark Månsson et al. (2003) is the latest study on Swedish dairy milk and will thus be used for comparisons with reference milk throughout this study.

Protein, CN, and whey protein content were found to be higher in the summer milk from the research herd SR $(P=0.003, P=0.000$, and $P=0.008$, respectively $)$ than in the research herd SH. When the different breeds in the research herd were compared with the SR herd and the SH herd on normal farms, the protein 
Table 1. Unadjusted means and standard deviations (in parentheses) of protein and lipid profiles together with unadjusted means ${ }^{1}$ and standard deviations for fatty acids (FA) in summer milk samples from the research herd, the Swedish Red (SR) herd, the Swedish Holstein (SH) herd, reference milk, the research herd SR, and the research herd SH (df $=3)^{2}$

\begin{tabular}{|c|c|c|c|c|c|c|}
\hline \multirow[b]{2}{*}{ Component } & \multicolumn{6}{|c|}{ Summer } \\
\hline & Research herd & SR herd & SH herd & Reference milk & Research herd SR & Research herd SH \\
\hline $\begin{array}{l}\text { Milk yield }(\mathrm{kg}) \\
\text { Protein }(\mathrm{g} / 100 \mathrm{~g}) \\
\text { Protein yield }(\mathrm{kg}) \\
\mathrm{CN}(\mathrm{g} / 100 \mathrm{~g}) \\
\mathrm{CN} \text { yield }(\mathrm{kg}) \\
\text { CN number } \\
\text { Whey proteins }(\mathrm{g} / 100 \mathrm{~g}) \\
\text { Whey protein yield }(\mathrm{kg}) \\
\text { CN:whey protein ratio } \\
\text { NPN }(\mathrm{g} / 100 \mathrm{~g}) \\
\text { NPN yield }(\mathrm{g}) \\
\text { Urea }(\mathrm{mmol} / \mathrm{L}) \\
\text { Lipid }(\mathrm{g} / 100 \mathrm{~g}) \\
\text { Lipid yield }(\mathrm{kg}) \\
\text { FFA }(\mathrm{mEq} / \mathrm{L}) \\
\text { Sum of } \mathrm{C}_{20} \text { and }>\mathrm{C}_{20} \\
\text { Sum of } \mathrm{n}-3 \mathrm{FA} \\
\text { Sum of } \mathrm{n}-6 \mathrm{FA} \\
\text { n- } 6 \text { FA:n-3 FA ratio } \\
\text { Sum of saturated FA } \\
\text { Sum of monounsaturated FA } \\
\text { Sum of polyunsaturated FA }\end{array}$ & $\begin{array}{l}34.8(1.7) \\
3.26(0.06) \\
1.13(0.08) \\
2.50(0.06) \\
0.87(0.06) \\
0.77(0.00) \\
0.57(0.01) \\
0.20(0.01) \\
4.40(0.10) \\
0.030(0.000) \\
10.4(0.5) \\
5.25(0.35) \\
3.66(0.03) \\
1.27(0.05) \\
0.59(0.05) \\
1.03(0.32) \\
1.38(0.05) \\
2.45(0.17) \\
1.78(0.18) \\
63.2(0.4) \\
29.3(0.5) \\
4.43(0.15)\end{array}$ & $\begin{array}{c}23.9^{* * *}(1.0) \downarrow \\
3.55^{* * *}(0.06) \uparrow \\
0.85^{* *}(0.05) \downarrow \\
2.74^{* * *}(0.05) \uparrow \\
0.66^{* *}(0.04) \downarrow \\
0.77^{\text {NS }}(0.00) \uparrow \\
0.60^{* *}(0.01) \uparrow \\
0.14^{* *}(0.01) \downarrow \\
4.59^{*}(0.03) \uparrow \\
0.034^{* * *}(0.001) \uparrow \\
8.07^{* *}(0.41) \downarrow \\
6.38^{* *}(0.17) \uparrow \\
4.02^{* * *}(0.07) \uparrow \\
0.96^{* * *}(0.03) \downarrow \\
0.47^{*}(0.05) \downarrow \\
1.03^{\text {NS }}(0.13) \uparrow \\
1.53^{* *}(0.05) \uparrow \\
1.73^{* *}(0.25) \downarrow \\
1.13^{* *}(0.12) \downarrow \\
64.4^{*}(0.6) \uparrow \\
28.7^{\text {NS }}(0.6) \\
3.90^{* *}(0.14) \downarrow\end{array}$ & $\begin{array}{l}30.5^{*}(0.4) \downarrow \\
3.39^{*}(0.02) \uparrow \\
1.03^{\mathrm{NS}}(0.02) \\
2.34^{* *}(0.04) \downarrow \\
0.71^{*}(0.02) \downarrow \\
0.69^{* * *}(0.01) \downarrow \\
0.77^{* * *}(0.02) \uparrow \\
0.23^{* *}(0.01) \uparrow \\
3.06^{* * *}(0.10) \downarrow \\
0.045^{* *}(0.004) \uparrow \\
13.6^{* *}(1.2) \uparrow \\
5.70^{\mathrm{NS}}(0.46) \\
3.73^{\mathrm{NS}}(0.08) \\
1.14^{* *}(0.01) \downarrow \\
0.54^{\mathrm{NS}}(0.06) \\
1.03^{\mathrm{NS}}(0.17) \\
1.03^{* * *}(0.05) \downarrow \\
2.40^{\mathrm{NS}}(0.14) \\
2.34^{* *}(0.05) \uparrow \\
64.7^{* *}(0.6) \uparrow \\
28.1^{*}(0.5) \downarrow \\
4.23^{\mathrm{NS}}(0.21)\end{array}$ & $\begin{array}{l}3.37^{*} \overline{(0.03) \uparrow} \\
2.54^{\mathrm{NS}}(0.01) \\
0.75^{*} \overline{(0.01) \downarrow} \\
0.62^{* *}(0.02) \uparrow \\
4.10^{*} \overline{(0.14) \downarrow} \\
0.030^{*}(0.002) \\
5.48^{\mathrm{NS}}(0.17) \\
3.98^{* * *}(0.03) \uparrow \\
0.59^{\mathrm{NS}}-(0.04) \\
1.18^{\mathrm{NS}}(0.05) \\
1.38^{\mathrm{NS}}(0.05) \\
2.08^{*}(0.10) \downarrow \\
1.51^{\mathrm{NS}}(0.10) \\
64.1^{*}(0.4) \uparrow \\
28.6^{\mathrm{NS}}(0.3) \\
4.25^{\mathrm{NS}}(0.10)\end{array}$ & $\begin{array}{l}32.3^{\mathrm{NS}}(2.1) \\
3.40^{*}(0.05) \uparrow \\
1.10^{\mathrm{NS}}(0.09) \\
2.55^{\mathrm{NS}}(0.04) \\
0.82^{\mathrm{NS}}(0.07) \\
0.75^{* * *}(0.00) \downarrow \\
0.65^{* * *}(0.02) \uparrow \\
0.21^{\mathrm{NS}}(0.02) \\
3.95^{* *}(0.06) \downarrow \\
0.033^{* *}(0.001) \uparrow \\
10.5^{\mathrm{NS}}(0.5) \\
5.05^{\mathrm{NS}}(0.24) \\
3.97^{* * *}(0.06) \uparrow \\
1.28^{\mathrm{NS}}(0.10) \\
0.47^{*}(0.02) \downarrow \\
1.20^{\mathrm{NS}}(0.26) \\
1.30^{\mathrm{NS}}(0.08) \\
2.38^{\mathrm{NS}}(0.32) \\
1.82^{\mathrm{NS}}(0.17) \\
63.6^{\mathrm{NS}}(1.0) \\
29.3^{\mathrm{NS}}(0.6) \\
4.35^{\mathrm{NS}}(0.35)\end{array}$ & $\begin{array}{l}37.9^{\mathrm{NS}}(2.3) \\
3.19^{\mathrm{NS}}(0.01) \\
1.21^{\mathrm{NS}}(0.08) \\
2.40^{*}(0.01) \downarrow \\
0.91^{\mathrm{NS}}(0.05) \\
0.75^{* * *}(0.00) \downarrow \\
0.59^{* *}(0.01) \uparrow \\
0.22^{*}(0.01) \uparrow \\
4.07^{* *}(0.04) \downarrow \\
0.032^{\mathrm{NS}}(0.002) \\
12.1^{\mathrm{NS}}(1.3) \\
5.35^{\mathrm{NS}}(0.24) \\
3.60^{*}(0.02) \downarrow \\
1.36^{\mathrm{NS}}(0.09) \\
0.53^{\mathrm{NS}}(0.03) \\
1.13^{\mathrm{NS}}(0.05) \\
1.43^{\mathrm{NS}}(0.10) \\
2.43^{\mathrm{NS}}(0.10) \\
1.71^{\mathrm{NS}}(0.09) \\
61.9^{*}(0.7) \downarrow \\
30.3^{*}(0.3) \uparrow \\
4.75^{*}(0.19) \uparrow\end{array}$ \\
\hline \multicolumn{7}{|c|}{$\begin{array}{l}{ }^{1} \text { Mean FA as a proportion (wt/wt) of the total fat fraction of } 100 \% \text {. } \\
{ }^{2} \text { Yields are given per cow per day. } P \text {-values are for differences between the research herd and the SR herd, the SH herd, reference milk, the research herd SR, and the research he } \\
\text { SH, and arrows indicate the direction of the change. } \\
{ }^{*} P<0.05 ; * * P<0.01 ; * * * P<0.001 \text {. }\end{array}$} \\
\hline
\end{tabular}


Table 2. Unadjusted means and standard deviations (in parentheses) of protein and lipid profiles in winter milk samples from the research herd, the Swedish Red (SR) herd, the Swedish Holstein $(\mathrm{SH})$ herd, and reference milk $(\mathrm{df}=3)^{1}$

\begin{tabular}{|c|c|c|c|c|}
\hline \multirow[b]{2}{*}{ Component } & \multicolumn{4}{|c|}{ Winter } \\
\hline & Research herd & SR herd & SH herd & Reference milk \\
\hline Protein $(\mathrm{g} / 100 \mathrm{~g})$ & $3.52(0.02)$ & $3.48^{*}(0.01) \downarrow$ & $3.39^{* * *}(0.02) \downarrow$ & $3.38^{* *}(0.03) \downarrow$ \\
\hline Protein yield $(\mathrm{kg})$ & $1.29(0.03)$ & $0.93^{* * *}(0.03) \downarrow$ & $1.09 * * *(0.01) \downarrow$ & \\
\hline $\mathrm{CN}(\mathrm{g} / 100 \mathrm{~g})$ & $2.62(0.13)$ & $2.72^{\mathrm{NS}}(0.00)$ & $2.61^{\mathrm{NS}}(0.02)$ & $2.60^{\mathrm{NS}}(0.02)$ \\
\hline CN yield (kg) & $0.96(0.06)$ & $0.73^{* *}(0.02) \downarrow$ & $0.84^{*}(0.01) \downarrow$ & \\
\hline Whey protein yield $(\mathrm{kg})$ & $0.26(0.04)$ & $0.15^{* *}(0.00) \downarrow$ & $0.18^{*}(0.00) \downarrow$ & - \\
\hline $\mathrm{CN}$ :whey protein ratio & $3.85(0.82)$ & $4.70^{\mathrm{NS}}(0.12)$ & $4.55^{\mathrm{NS}}(0.05)$ & $4.40^{\mathrm{NS}}(0.14)$ \\
\hline NPN $(g / 100 g)$ & $0.032(0.001)$ & $0.029^{* * *}(0.001) \downarrow$ & $0.032^{\mathrm{NS}}(0.001)$ & $0.030^{* *}(0.001) \downarrow$ \\
\hline NPN yield $(\mathrm{g})$ & $11.7(0.3)$ & $7.59^{* * *}(0.06) \downarrow$ & $10.3^{* *}(0.3) \downarrow$ & - \\
\hline Urea $(\mathrm{mmol} / \mathrm{L})$ & $5.23(0.29)$ & $4.80^{*}(0.14) \downarrow$ & $5.70^{\mathrm{NS}}(0.36)$ & $5.05^{\mathrm{NS}}(0.13)$ \\
\hline Lipid (g/100 g) & $3.77(0.06)$ & $4.14^{* * *}(0.04) \uparrow$ & $3.84^{\mathrm{NS}}(0.08)$ & $4.21 * *(0.12) \uparrow$ \\
\hline Lipid yield (kg) & $1.38(0.04)$ & $1.10^{* * *}(0.02) \downarrow$ & $1.23^{* *}(0.04) \downarrow$ & - \\
\hline
\end{tabular}

${ }^{1}$ Yields are given per cow per day. $P$-values are for differences between the research herd and the SR herd, the SH herd, and reference milk, and arrows indicate the direction of the change.

${ }^{*} P<0.05 ;{ }^{* *} P<0.01 ;{ }^{* * *} P<0.001$.

content was found to be lower in the milk of both the research herd SR $(P=0.009)$ and the research herd SH $(P=0.000)$. Furthermore, milk from the research herd SR had a lower $\mathrm{CN}$ content $(P=0.001)$ and a higher whey protein content $(P=0.005)$ than SR herd milk, whereas milk from the research herd $\mathrm{SH}$ had a higher CN content $(P=0.035)$ and a lower content of whey proteins $(P=0.000)$ than SH herd milk.

Regarding minor nitrogen compounds, no difference was observed in the urea content in research herd milk and reference milk, whereas differences were found in NPN between research herd milk and reference milk in both winter and summer $(P=0.010$ and $P=0.031$, respectively). However, the content of NPN in reference milk was in accordance with the average value previously observed in Swedish dairy milk (Lindmark Månsson et al., 2003). No differences were observed in minor nitrogen compounds in milk from the different breeds in the research herd.

Lipid Profile. The contents of lipids and FFA as well as the FA composition and the seasonal variations were also determined (Tables 1, 2, 3, and 4). The lipid content of the research herd milk showed a seasonal variation $(P=0.032)$, and lower contents of lipids in both winter $(P=0.003)$ and summer $(P=$ $0.000)$ samples than in the reference milk. Additionally, the lipid content of the reference milk in both winter and summer was lower than the average fat content previously reported for dairy milk in Sweden [4.34 g/100 g (SD 0.07); Lindmark Månsson et al., 2003], and seasonal variation was also found $(P=$ 0.035), which was not observed by Lindmark Månsson et al. (2003). In addition to the important nutritive aspect of milk fat, it is the main raw material in the manufacture of cream and butter. Thus, a lower lipid content will reduce the yields of butter and cream, and also affect the consistency of cheese (Walstra et al., 1999).

Summer milk samples from the research herd SR and the research herd $\mathrm{SH}$ showed a difference in lipid content $(P=0.002)$, with the milk from the SH cows having a lower content. The same observation was made regarding milk from the SR herd and the SH herd $(P=$ 0.002). The lipid content in milk from the research herd $\mathrm{SH}$ was lower than that in SH herd milk $(P=0.048)$, whereas no difference could be seen in the lipid content of milk from the research herd SR and the SR herd.

Free fatty acids are formed during the lipolysis of milk, and a high content may give the milk a rancid taste (Tuckey and Stadhouders, 1967; Shipe et al., 1980). Seasonal variations were observed for all the herds and the reference milk, with the lowest values being found in winter milk samples. The content of FFA was lower in research herd winter milk than in reference winter milk $(P=0.000)$, whereas no differences were observed between summer milk samples. A lower content of FFA was observed in summer milk from the research herd SR than from the research herd SH $(P=0.025)$, whereas no differences were seen between the different research herd breeds and the SR and SH herds. The content of FFA in milk from individual cows have been shown to increase with increased milking frequency (Klei et al., 1997; Wiking et al., 2006), but even though the research herd was milked 3 times a day, compared with 
Table 3. $P$-values for seasonal variations in the protein, lipid, and carbohydrate profiles and the mineral content, as well as in SCC, freezing point, and $\mathrm{pH}$ in milk samples from the research herd, the Swedish Red (SR) herd, the Swedish Holstein (SH) herd, and reference milk (df = 3)

\begin{tabular}{|c|c|c|c|c|}
\hline Component & Research herd & SR herd & SH herd & Reference milk \\
\hline Protein $(\mathrm{g} / 100 \mathrm{~g})$ & $* *$ & NS & NS & NS \\
\hline Protein yield (kg) & * & * & * & - \\
\hline CN (g/100 g) & NS & NS & $* * *$ & $* *$ \\
\hline $\mathrm{CN}$ yield $(\mathrm{kg})$ & NS & $*$ & ** & - \\
\hline $\mathrm{CN}$ number & NS & ** & $* * *$ & * \\
\hline Whey proteins $(\mathrm{g} / 100 \mathrm{~g})$ & NS & NS & $* * *$ & NS \\
\hline Whey protein yield $(\mathrm{kg})$ & NS & NS & $* * *$ & - \\
\hline $\mathrm{CN}$ :whey protein ratio & NS & NS & $* * *$ & * \\
\hline NPN $(g / 100 \mathrm{~g})$ & $* *$ & $* * *$ & $* *$ & $*$ \\
\hline NPN yield $(\mathrm{g})$ & $* *$ & NS & * & - \\
\hline Urea $(\mathrm{mmol} / \mathrm{L})$ & NS & $* * *$ & NS & * \\
\hline Lipid (g/100 g) & * & * & NS & * \\
\hline Lipid yield (kg) & * & $* *$ & * & - \\
\hline FFA $(\mathrm{mEq} / \mathrm{L})$ & $* * *$ & ** & $* * *$ & $* * *$ \\
\hline Lactose $(\mathrm{g} / 100 \mathrm{~g})$ & NS & NS & NS & NS \\
\hline Lactose yield (kg) & NS & ** & ** & - \\
\hline Lactic acid (mg/L) & $* *$ & ** & $* *$ & $* *$ \\
\hline Calcium (mg/100 g) & $*$ & NS & $*$ & NS \\
\hline Calcium yield (g) & NS & NS & NS & - \\
\hline Phosphorus (mg/100 g) & $* *$ & *** & $* *$ & * \\
\hline Phosphorus yield (g) & ** & NS & * & - \\
\hline Potassium (mg/100 g) & $* * *$ & $* *$ & $* * *$ & $* * *$ \\
\hline Potassium yield (g) & * & NS & * & - \\
\hline Magnesium (mg/100 g) & $* *$ & * & ** & * \\
\hline Magnesium yield $(\mathrm{g})$ & * & NS & NS & - \\
\hline Zinc $(\mathrm{mg} / 100 \mathrm{~g})$ & * & NS & NS & $* *$ \\
\hline Zinc yield (g) & * & ** & NS & - \\
\hline $\mathrm{SCC}(\log / \mathrm{mL})$ & NS & * & NS & * \\
\hline Freezing point $\left({ }^{\circ} \mathrm{C}\right)$ & NS & NS & NS & * \\
\hline $\mathrm{pH}$ & NS & NS & NS & NS \\
\hline
\end{tabular}

twice a day for the SR and SH herds, the content of FFA tended to be low.

The importance of FA composition in milk has increased in the dairy industry in recent years because of consumers' increased awareness of human health aspects. In summer milk samples, the research herd milk had a lower amount of saturated FA $(P=0.028)$ and higher amounts of n-6 FA $(P=0.019)$ than reference milk, whereas no differences were observed for n-3 FA. Recently, a high ratio of n- 6 to n-3 FA has been presented as promoting the pathogenesis of many diseases, including cardiovascular and inflammatory diseases, whereas a low ratio exerts suppressive effects, and today the recommendation is a ratio of less than or equal to 5 (French Food Safety Agency, 2002). No difference was seen between research herd milk and reference milk regarding the ratio of n- 6 to n- 3 FA, and all the ratios found in this study were lower than the recommended value. When the different breeds in the research herd were compared, a higher amount of saturated FA (C4:0 to C14:0; $P=0.001$ to 0.048$)$ and a lower amount of monounsaturated FA $(P=0.040)$ were found in milk from the SR cows than in milk from the SH cows. Furthermore, the different breeds in the research herd had on average a higher amount of unsaturated $\mathrm{C} 18: 1$ isomers $(P=0.000$ to 0.015$)$, which have positive effects on human health, in milk than did milk from the SR and SH herds.

Carbohydrate Profile. The lactose (anhydrous) content of research herd milk varied between 4.51 $\mathrm{g} / 100 \mathrm{~g}$ (SD 0.03) in winter and $4.54 \mathrm{~g} / 100 \mathrm{~g}$ (SD 0.01) in summer (Tables 3, 5, and 6). No differences could be seen between research herd milk and reference milk, and the lactose content of the reference milk was in accordance with the previously determined average lactose (anhydrous) content of Swedish dairy milk [4.56 g/100 g (SD 0.05); Lindmark Månsson et al., 2003]. A lower lactose content was found in summer milk from the research herd SR than in summer milk from the research herd SH $(P=0.006)$; the same observation was made in milk from the SR and SH herds $(P=0.000)$. Furthermore, the lactose content was higher in summer samples of milk from research herd SR cows than in summer milk samples from SR herd cows $(P=0.008)$. No seasonal variations were found in any of the herds or the reference milk, which is in contrast to results found previously for farm and dairy milk (Auldist et al., 1998; Lindmark Månsson et al., 2003). 
Table 4. Unadjusted means ${ }^{1}$ and standard deviations (in parentheses) for fatty acid composition in summer milk samples from the research herd, the Swedish Red (SR) herd, the Swedish Holstein (SH) herd, reference milk, the research herd SR, and the research herd SH $(\mathrm{df}=3)^{2}$

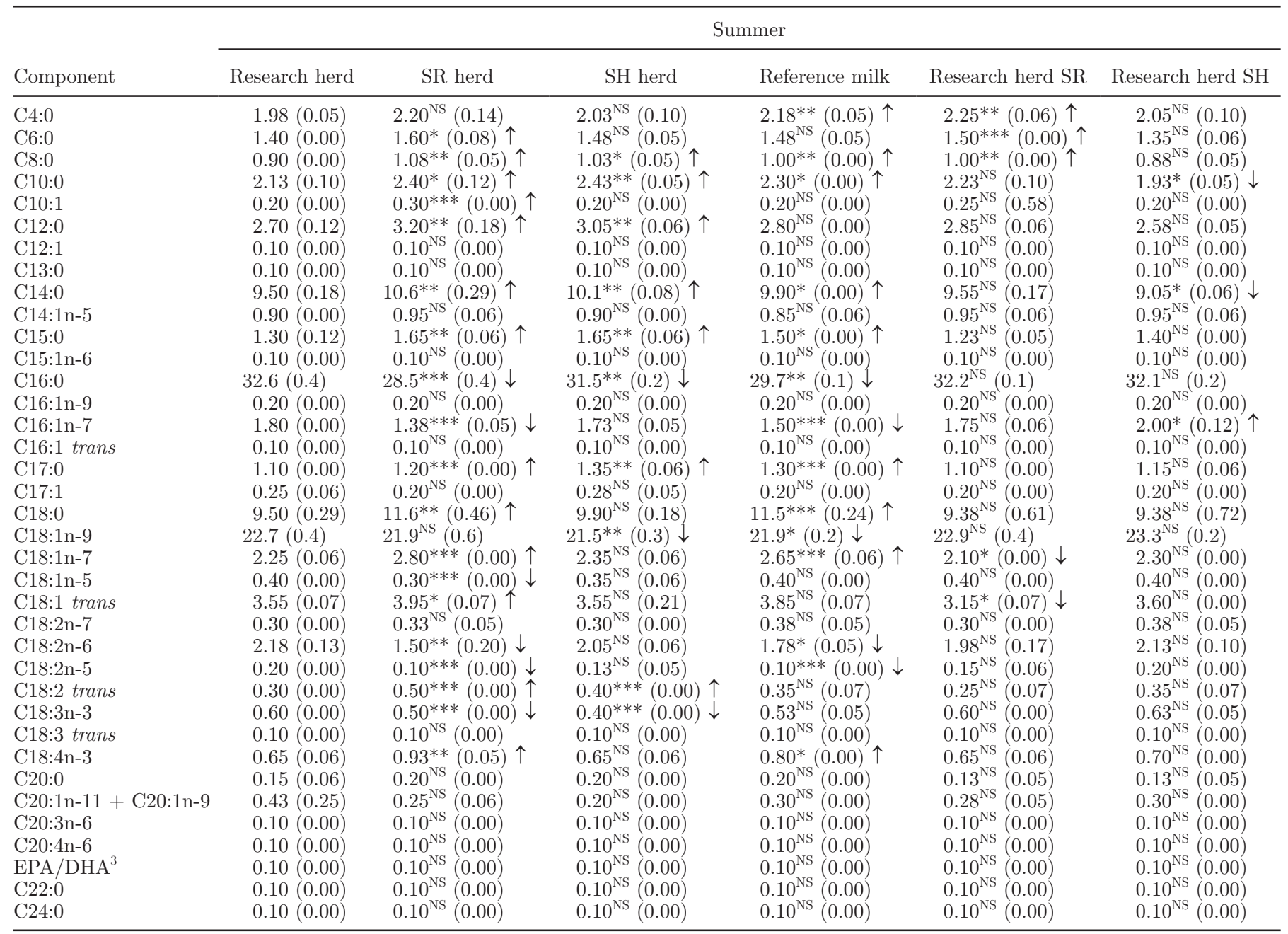

${ }^{1}$ Mean fatty acid as a proportion (wt/wt) of the total fat fraction of $100 \%$.

${ }^{2} P$-values are for differences between the research herd and the SR herd, the SH herd, reference milk, the research herd SR, and the research herd $\mathrm{SH}$, and arrows indicate the direction of the change.

${ }^{3} \mathrm{EPA}=\mathrm{C} 20: 5 \mathrm{n}-3 ; \mathrm{DHA}=\mathrm{C} 22: 6 \mathrm{n}-3$.

${ }^{*} P<0.05 ;{ }^{* *} P<0.01 ;{ }^{* * *} P<0.001$.

Lactose can be fermented into lactic acid by most of the bacteria growing in milk; thus, the reaction is desirable in the production of fermented milk products but is undesirable in milk intended for liquid consumption (Walstra et al., 1999). All the herds and the reference milk showed a seasonal variation, with higher contents of lactic acid being found in summer milk samples $(P$ $=0.001$ to 0.008 ). No differences in lactic acid content were observed between research herd milk and reference milk or between the different breeds.

Minerals. The mineral contents and seasonal variations are summarized in Tables 3, 5, and 6. All the values in research herd milk were lower in winter than in summer $(P=0.000$ to 0.026$)$, as was the case in the reference milk ( $P=0.000$ to 0.024 ), except for the calcium content. Compared with previous findings for Swedish dairy milk (Lindmark Månsson et al., 2003), the reference winter milk in this study had a lower mineral content. The lower values observed in winter milk could be due to actual seasonal variation or to analytical errors. No differences were seen for any of the minerals between research herd milk and reference milk in summer samples, and the mineral content in reference summer milk was in accordance with the average values previously reported for Swedish dairy milk. Lindmark Månsson et al. (2003) determined the mineral content of Swedish dairy milk by using atomic absorption spectrometry, whereas the method used in 
Table 5. Unadjusted means and standard deviations (in parentheses) of carbohydrate profile and mineral content as well as SCC, freezing point, and $\mathrm{pH}$ in winter milk samples from the research herd, the Swedish Red (SR) herd, the Swedish Holstein (SH) herd, and reference milk $(\mathrm{df}=3)^{1}$

\begin{tabular}{|c|c|c|c|c|}
\hline Component & \multicolumn{4}{|c|}{ Winter } \\
\hline Lactose (g/100 g) & $4.51(0.03)$ & $4.42^{* * *}(0.02) \downarrow$ & $4.59^{*}(0.01) \uparrow$ & $4.47^{\mathrm{NS}}(0.03)$ \\
\hline Lactic acid $(\mathrm{mg} / \mathrm{L})$ & $6.86(0.44)$ & $5.77^{*}(0.55) \downarrow$ & $6.49^{\mathrm{NS}}(0.21)$ & $7.18^{\mathrm{NS}}(0.10)$ \\
\hline Calcium (mg/100 g) & $104(4)$ & $104^{\mathrm{NS}}(5)$ & $111^{*}(2) \uparrow$ & $109^{*}(2) \uparrow$ \\
\hline Calcium yield $(\mathrm{g})$ & $38.0(1.0)$ & $27.6^{* * *}(0.7) \downarrow$ & $35.5^{*}(0.5) \downarrow$ & \\
\hline Potassium (mg/100 g) & $150(3)$ & $151^{\mathrm{NS}}(2)$ & $152^{\mathrm{NS}}(3)$ & $148^{\mathrm{NS}}(2)$ \\
\hline Potassium yield $(\mathrm{g})$ & $54.9(0.7)$ & $40.3^{* * *}(1.0) \downarrow$ & $48.6^{* * * *}(0.5) \downarrow$ & \\
\hline Magnesium (mg/100 g) & $10.0(0.4)$ & $10.1^{\mathrm{NS}}(0.4)$ & $9.80^{\mathrm{NS}}(0.10)$ & $10.3^{\mathrm{NS}}(0.2)$ \\
\hline Magnesium yield (g) & $3.67(0.11)$ & $2.69^{* * *}(0.06) \downarrow$ & $3.14^{* *}(0.05) \downarrow$ & - \\
\hline Zinc $(\mathrm{mg} / 100 \mathrm{~g})$ & $0.45(0.01)$ & $0.46^{\mathrm{NS}}(0.03)$ & $0.43^{\mathrm{NS}}(0.02)$ & $0.42^{* *}(0.00) \downarrow$ \\
\hline Zinc yield (g) & $0.17(0.00)$ & $0.12^{* * *}(0.01) \downarrow$ & $0.14^{* *}(0.01) \downarrow$ & - \\
\hline $\mathrm{SCC}(\log / \mathrm{mL})$ & $5.19(4.08)$ & $5.03^{* * *}(3.92) \downarrow$ & $5.23^{\mathrm{NS}}(4.41)$ & $5.33^{* * *}(4.15) \uparrow$ \\
\hline
\end{tabular}

${ }^{1}$ Yields are given per cow per day. $P$-values are for differences between the research herd and the SR herd, the SH herd, and reference milk, and arrows indicate the direction of the change.

${ }^{*} P<0.05 ; * * P<0.01 ; * * * P<0.001$.

the present study was inductively coupled plasma mass spectroscopy. The different methods used could have affected the results obtained.

On comparing summer milk from the different breeds in the research herd, no difference was found except in the magnesium content, with the SR cows having a higher magnesium content $(P=0.001)$. Nor were any differences observed between the research herd SR and the SR herd regarding mineral content in summer milk samples. However, summer milk from the SH herd had higher calcium and phosphorus contents $(P=0.024$ and $P=0.024$, respectively) than summer milk from the research herd $\mathrm{SH}$.

$S C C$, Freezing Point, and $\boldsymbol{p H}$. Somatic cell count, freezing point, and $\mathrm{pH}$, as well as their seasonal variation, are presented in Tables 3,5 , and 6 . The $\mathrm{pH}$ varied within the range found previously in milk from individual cows for all the herds and for the reference milk (Ikonen et al., 2004; Tyrisevä et al., 2004; Wedholm et al., 2006a), and no seasonal variation was detected. For the research herd, the $\mathrm{pH}$ varied between 6.73 (SD 0.02) in winter milk and 6.71 (SD 0.01) in summer milk. The freezing point depression of milk is essentially constant because of its proportionality to the osmotic pressure, and the observed values were in the range published earlier for farm milk and the milk of individual cows (Slaghuis, 2001; Henno et al., 2008). Seasonal variation was found for reference milk $(P=0.023)$, in accordance with previous values published for Swedish dairy milk (Lindmark Månsson et al., 2003). The SCC was lower in the milk from all the herds studied than in the reference milk ( $P=0.000$ to 0.041$)$, and the SCC in the reference milk was in the range found previously (Lindmark Månsson et al., 2003).

\section{Genetic Progress in Relation to Milk Yield}

Milk recording is of interest to both the farmer and members of the dairy industry. Despite this, data on yields of various milk components are limited, and usually only the yields of proteins, lipids, lactose, and urea are determined. To obtain knowledge concerning genetic progress in relation to milk yield, this extensive investigation was carried out on various milk components for the 3 different herds. The results are summarized in Tables 1, 2, 5, and 6 .

The research herd showed higher yields of all the milk components analyzed (i.e., protein, lipids, and carbohydrate contents, as well as minerals) in both winter $(P$ $=0.000$ to 0.006$)$ and summer samples $(P=0.000$ to $0.023)$ than did the SR herd. The same observation was made when comparing winter samples from the research herd and the $\mathrm{SH}$ herd $(P=0.000$ to 0.029$)$. In summer milk samples, the SH herd had higher yields of whey proteins $(P=0.004)$ and NPN $(P=0.008)$ than did the research herd, whereas no differences were seen for the yields of proteins and zinc. For all the other milk components analyzed, however, higher yields were found in research herd summer milk than in $\mathrm{SH}$ herd summer milk ( $P=0.001$ to 0.020$)$. In addition, summer samples from the different breeds in the research herd indicated higher yields. For summer milk samples, 
the research herd SR had higher yields for all the milk components studied than did the SR herd $(P=0.001$ to $0.023)$, as was also the case when the research herd $\mathrm{SH}$ was compared with the SH herd $(P=0.002$ to 0.035$)$, except for the yields of whey proteins and NPN, which showed no differences.

The cows in the research herd were milked 3 times a day, but the SR and SH herds were milked only twice a day. However, the milk yield of the research herd SR was $35 \%$ higher than that of the SR herd, and the milk yield of the research herd SH was $24 \%$ higher than that of the SH herd (Table 1), and it is unlikely that milking frequency would have increased the milk yield to this extent. The observed results thus indicate genetic progress in relation to milk yield, showing the possibility of using genetic selection to increase the yields of various milk components. Although some of the differences in the content of milk componenets between the research herd and the other studied herds are small but significant, the influence of the milk volume produced resulted in significantly increased yields of these components. It is therefore important to compare both the content and yield of milk components.

As stated above, elite dairy cows in the research herd produced milk containing a higher level of lactose than did cows in the SR and SH herds. Lactose is the starting material for lactic acid bacteria, which produce lactic acid, aromas, and carbon dioxide, and thus give fermented milk products and cheese the desired consistency, taste, and storage stability. The synthesis of lactose occurs in several steps and is an energy-demanding process (Walstra and Jenness, 1984). Thus, elite dairy cows in this study are being bred to produce high amounts of the energy-demanding component lactose.

\section{Genetic Progress in Relation to Milk Processability}

Gel Strength and Gelation Time. The proportion of milk produced in Sweden that is processed into other products has increased during recent decades, and today $34 \%$ is used to make cheese (Swedish Dairy Association, 2007). Good gelation characteristics are essential for maintaining the quality and yield of cheese, and rheological measurements were made during rennet-induced gelation to obtain the gel strength and gelation time of the milk samples (Figures 1 and 2). No differences were observed in gel strength or gelation time between research herd milk and reference milk in the winter samples. However, in summer samples, research herd milk had a higher gel strength $(P=0.011)$ and a shorter gelation time $(P=0.035)$ than reference milk, thus indicating good gelation characteristics. This is in accordance with the results observed for the $\mathrm{CN}$ number (Tables 1 and 2). No differences were found 


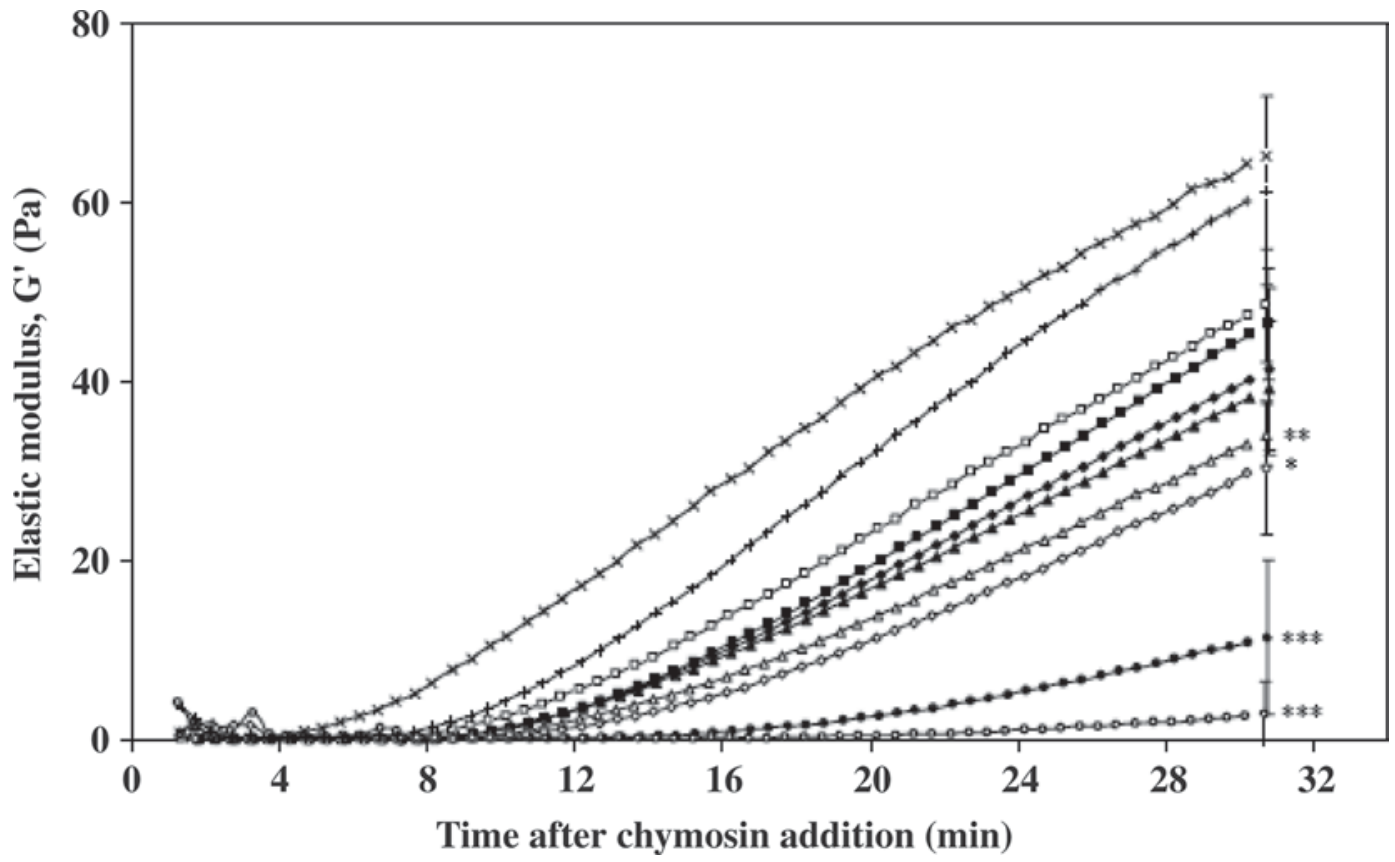

Figure 1. Gel strength determined as gel elasticity (elastic modulus; $\mathrm{G}^{\prime}$ ) with low-amplitude oscillation measurements in winter milk samples from the research herd $(\boldsymbol{\square})$, the Swedish Red (SR) herd $(\bullet)$, the Swedish Holstein (SH) herd $(\boldsymbol{\Delta})$, and reference milk $(\bullet)$, together with results from summer milk samples from the research herd $(\square)$, the SR herd $(\bigcirc)$, the SH herd $(\Delta)$, reference milk $(\diamond)$, the research herd SR $(+)$, and the research herd SH $(x ; \mathrm{df}=3)$. $P$-values are for differences between the research herd and the SR herd, the SH herd, reference milk, the research herd SR, and the research herd $\mathrm{SH}$ in winter and summer milk samples. ${ }^{*} P<0.05 ;{ }^{* *} P<0.01$; ${ }^{* * *} P<0.001$.

in gel strength or gelation time between the different breeds in the research herd. Differences, however, could be seen when comparing the breeds in the research herd with the SR and SH herds. The summer milk from the research herd SR and the research herd SH had a greater gel strength $(P=0.000$ and $P=0.022$, respectively) and shorter gelation time $(P=0.004$ and $P=$ 0.030 , respectively) than summer milk from the SR and $\mathrm{SH}$ herds. This once again indicates the good gelation characteristics of the milk from elite dairy cows. No seasonal variation was found in either of the parameters studied.

Fat Globule Size. The fat globule size in the milk samples was determined by light diffraction (Figure 3). No difference was found between research herd milk and reference milk in the winter, whereas in the summer the globules were larger in reference milk than in milk from the research herd $(P=0.003)$. No difference was observed in summer milk between the different breeds in the research herd. A seasonal variation was, however, found $(P=0.000)$ in SR herd milk, SH herd milk, and the reference milk, with smaller fat globules in summer milk. This is in accordance with the amount of FFA observed (Tables 1 and 2), with summer milk samples having a higher content of FFA. The milk lipids will either form fat globules or appear as FFA in the serum phase of milk.
Oxidation and TAC. Products of the primary and secondary phase of lipid oxidation and TAC in whey were determined (Figure 4) to investigate genetic progress in relation to oxidation and antioxidant capacity. Both the peroxide value, corresponding to the primary phase

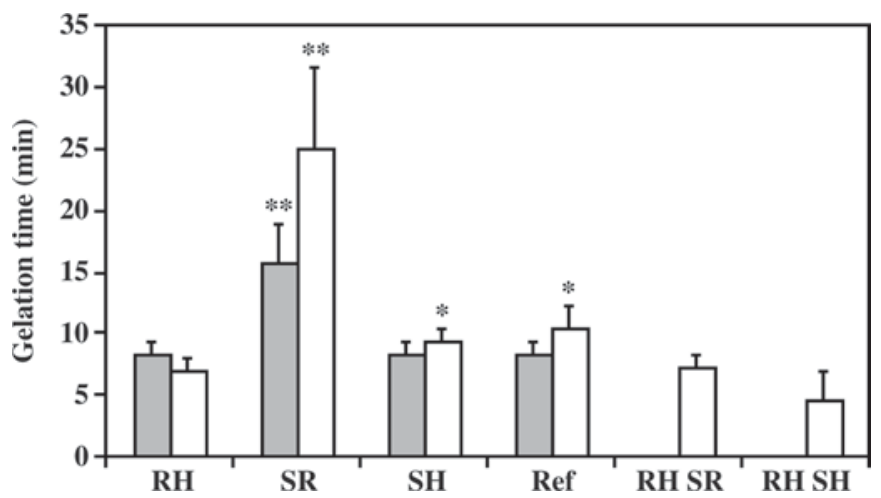

Figure 2. Rennet-induced gelation time, determined by low-amplitude oscillation measurements, in winter (gray bar) and summer (white bar) milk samples from the research herd $(\mathrm{RH})$, the Swedish Red herd (SR), the Swedish Holstein herd (SH), and reference milk (Ref; $\mathrm{df}=3$ ). The gelation time is also shown for summer milk samples from the research herd SR (RH SR) and the research herd SH $(\mathrm{RH}$ $\mathrm{SH} ; \mathrm{df}=3)$. $P$-values are for differences between the research herd and the SR herd, the SH herd, reference milk, the research herd SR, and the research herd $\mathrm{SH}$ in winter and summer milk samples. ${ }^{*} P<$ $0.05 ;{ }^{* *} P<0.01$. 


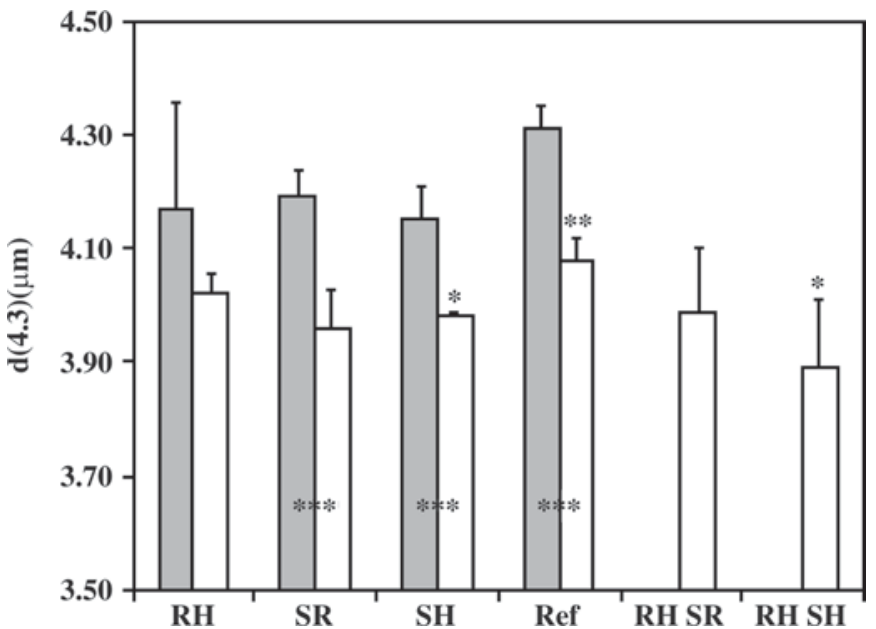

Figure 3. Volume-weighted droplet diameter, d(4,3), of the fat globules in winter (gray bar) and summer (white bar) milk samples from the research herd $(\mathrm{RH})$, the Swedish Red herd (SR), the Swedish Holstein herd $(\mathrm{SH})$, and reference milk (Ref; $\mathrm{df}=3$ ). Values are also shown for summer milk samples from the research herd SR (RH SR) and the research herd SH $(\mathrm{RH} \mathrm{SH} ; \mathrm{df}=3) . P$-values are for differences between the research herd and the SR herd, the SH herd, reference milk, the research herd SR, and the research herd $\mathrm{SH}$ in winter and summer milk samples. ${ }^{*} P<0.05 ;{ }^{* *} P<0.01 ;{ }^{* * *} P<0.001$.

of lipid oxidation, and the TBA value, corresponding to the secondary phase of lipid oxidation, were higher $(P$ $=0.020$ and $P=0.046$, respectively) in research herd milk than in the reference milk in winter, whereas no differences were observed for summer milk. The opposite, however, was seen for TAC in whey. Research herd summer milk had a lower TAC in whey $(P=0.042)$ than reference summer milk, whereas no differences were observed in winter milk. Thus, a lower TAC may increase the risk of further oxidation of the milk. The TAC in whole milk was analyzed but the results were deemed unreliable because of large variations. Even so, TAC was found to be higher in whole milk than in whey for all the herds and the reference milk (data not shown), which was expected because whey is included in the analysis of whole milk. A difference in the TBA value was found between the different breeds in the research herd, with $\mathrm{SH}$ cows having a lower value $(P$ $=0.004)$.

The rate at which lipid autooxidation occurs is known to be dependent on several factors, such as temperature, oxygen level, and FA composition (Walstra and Jenness, 1984). The more saturated FA the milk contains, the less susceptible the milk will be to autooxidation. However, no differences were found in peroxide or TBA values between research herd milk and reference milk during summer, although summer milk from the research herd was found to have a slightly lower amount of saturated FA than summer reference milk (Tables 1 and 4). Therefore, the higher amount of oxidation
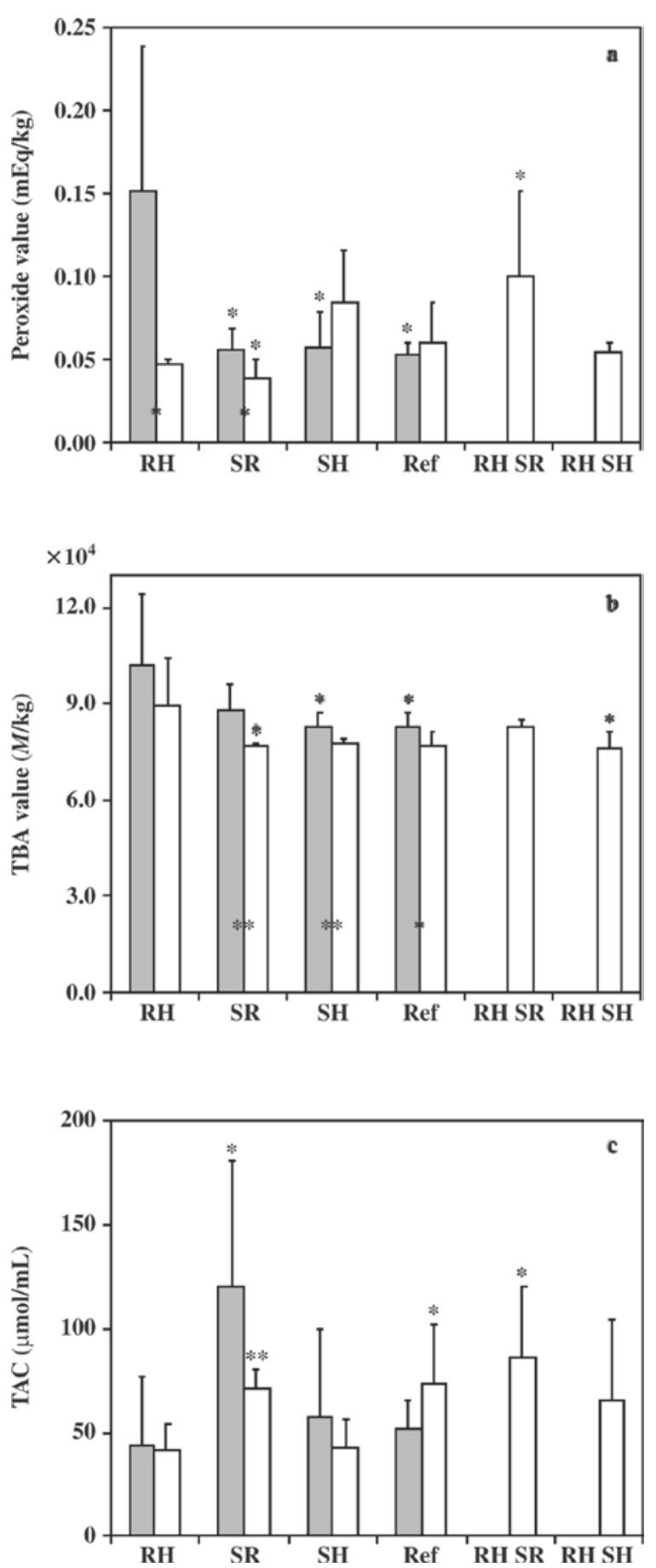

Figure 4. a) The peroxide value, corresponding to the primary phase of lipid oxidation; b) the thiobarbituric acid (TBA) value, corresponding to the secondary phase of lipid oxidation; and c) the total antioxidant capacity (TAC) in whey, in winter (gray bar) and summer (white bar) milk samples from the research herd (RH), the Swedish Red herd (SR), the Swedish Holstein herd (SH), and reference milk (Ref; df $=3)$. Values are also shown for summer milk samples from the research herd SR (RH SR) and the research herd SH (RH SH; df $=3)$. $P$-values are for differences between the research herd and the SR herd, the SH herd, reference milk, the research herd SR, and the research herd $\mathrm{SH}$ in winter and summer milk samples. ${ }^{*} P<0.05$; ${ }^{* *} P$ $<0.01$. 
products in research herd winter milk may be due to even lower levels of saturated FA.

\section{Differences Between Breeds}

In this study, we investigated the 2 most common breeds of dairy cattle in Sweden, SH (49.9\%) and SR (43.8\%; Swedish Dairy Association, 2008). In summer, the milk from the research herd SR had higher contents of components in the protein fraction $(P=0.000$ to $0.008)$ and a higher lipid content $(P=0.001)$, but a lower content of lactose $(P=0.006)$ than the milk from the research herd $\mathrm{SH}$. The same pattern was seen when comparing milk from the SR and SH herds in both winter and summer milk samples, and this is in accordance with previously published data for protein and lipid contents (Swedish Dairy Association, 2008). However, little difference in the yield of milk components could be seen between the different breeds in the research herd. The research herd $\mathrm{SH}$ cows gave higher yields of lactose $(P=0.007)$, calcium $(P=0.003)$, and magnesium $(P=$ $0.043)$. This is in contrast to data published previously on average yields of different Swedish dairy cow breeds (Swedish Dairy Association, 2008) and observations made when comparing the SR herd and the SH herd. Differences were found in the yields of all components in both winter $(P=0.000$ to 0.029$)$ and summer $(P$ $=0.000$ to 0.048$)$ samples, with the SH herd having higher yields of all components in both seasons.

Less variation in yields between the breeds of elite dairy cows may indicate that breeding strategies of today have reduced the differences in yields between the 2 most common dairy cow breeds in Sweden, but indicate no differences regarding the contents of milk components. A smaller difference between milk produced by the 2 breeds would mean a more uniform composition of the milk delivered to Swedish dairies, thus improving the quality of milk and reducing processability problems.

\section{General Discussion}

On average, the contents of some milk components were lower, especially during summer, in research herd milk than in reference milk, whereas the yield of milk components was higher in the research herd on a yearly basis. Such findings are important to improve our understanding of the effects of genetic selection. Although the Swedish breeding objective is to improve milk yields without decreasing the content of milk components (VikingGenetics, 2006), the results observed in this study indicate a decrease in the contents of some milk components in the milk from elite dairy cows. The same observation has been reported earlier. A negative genetic correlation exists between milk yield and fat $(-0.58)$, protein $(-0.39)$, and $\mathrm{CN}$ content $(-0.38)$ as well as C14 to C16 FA (-0.57; Ikonen et al., 2004; Schennink et al., 2008; Stoop et al., 2008), whereas a positive genetic correlation has been found between milk yield and milk urea nitrogen (0.24) and unsaturated $\mathrm{C}_{18}$ FA (0.43; Stoop et al., 2007, 2008). This indicates difficulties in increasing both the yield and content of milk components simultaneously through genetic selection. Thus, it is important to monitor the content of milk components for genetic selection programs. Lower contents will affect not only the nutritive value, but also the technological properties and processability of milk. Thus far, however, milk from the elite dairy cows studied here tends to have good rennet-induced gelation characteristics. On the other hand, milk from the elite cows is more susceptible to autooxidation, and has a lower TAC, both of which will negatively affect milk quality. These findings show clearly that the breeding program influences milk compostion, yield of milk components, and processability considerably, offering possibilities to alter milk quality globally through breeding.

A previous study performed on almost 2,000 winter milk samples from individual cows showed the potential to alter milk composition and yield through genetic selection (Stoop et al., 2008), and genes associated with milk fat and protein content, FA composition, and milk yield have been identified (Grisart et al., 2002; Schennink et al., 2007; Näslund et al., 2008). The results observed in this study for elite dairy cows indicate genetic progress in relation to milk yield, varying genetic progress in relation to milk processability, and a decrease in the contents of some milk components on average as a correlated response to selection for the Swedish breeding objective. Thus, the next step is to identify the genes controlling these traits, which will provide important specific information on how to adjust breeding practices to increase the contents of various milk components. This is of great importance to the dairy industry in maintaining a high milk quality, with regard to both nutrition and processability.

\section{CONCLUSIONS}

The results of this study have shown genetic progress in relation to milk yield for elite dairy cows, with higher yields for components of the protein, lipid, and carbohydrate profiles as well as minerals, whereas the content of some milk components has on average decreased as a correlated response to selection for the Swedish breeding objective. A lower content of milk components may affect both the nutritive value and the processability of milk. However, milk from elite dairy cows has good gelation characteristics, whereas it 
tends to be more susceptible to lipid autooxidation and has a lower TAC. Further studies are needed to obtain specific information on how breeding practices can be adjusted to maintain a high milk quality, with regard to both nutrition and processability.

\section{ACKNOWLEDGMENTS}

We thank Börje Ax (Luttra Skräddaretomten, Falköping, Sweden), Stefan Lennartsson (Luttra Majnegården, Falköping, Sweden), and Falköpings Mejeri (Falköping, Sweden) for providing milk samples, and for their help in collecting data. We also thank the staff at Nötcenter Viken (Falköping, Sweden), especially Lennart Johansson, for invaluable help during milking and the collection of data, as well as valuable discussions in the planning of the investigation. The Chy-Max Plus was a kind gift from Mikkel Laust Broe, Chr. Hansen A/S, Hørsholm, Denmark. This work was supported by grants from the Swedish Farmer's Foundation for Agricultural Research (SLF), Stockholm, Sweden.

\section{REFERENCES}

Amenu, B., and H. C. Deeth. 2007. The impact of milk composition on cheedar cheese manufacture. Aust. J. Dairy Technol. 62:171184 .

AOCS. 1997. Fatty acid composition by gas chromatography (AOCS official method Ce 1-62). American Oil Chemists' Society, Urbana, IL.

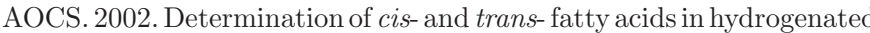
and refined oils and fats by capillary GLC (AOCS official method Ce 1f-96). American Oil Chemists' Society, Urbana, IL.

Auldist, M. J., B. J. Walsh, and N. A. Thomson. 1998. Seasonal and lactational influences on bovine milk composition in New Zealand. J. Dairy Res. 65:401-411.

Chen, J., H. Lindmark-Månsson, L. Gorton, and B. Åkesson. 2003. Antioxidant capacity of bovine milk as assayed by spectrophotometric and amperometric methods. Int. Dairy J. 13:927-935.

Falköpings Mejeri. 2007. Annual report 2006/2007. Falköpings Mejeri, Falköping, Sweden.

French Food Safety Agency. 2002. The Omega 3 Fatty Acids and the Cardiovascular System: Nutritional Benefits and Claims. French Food Safety Agency, Maisons-Alfort, France.

Grisart, B., W. Coppieters, F. Farnir, L. Karim, C. Ford, P. Berzi, N. Cambisano, M. Mni, S. Reid, P. Simon, R. Spelman, M. Georges, and R. Snell. 2002. Positional candidate cloning of a QTL in dairy cattle: Identification of a missense mutation in the bovine DGAT1 gene with major effect on milk yield and composition. Genome Res. 12:222-231.

Hallén, E., T. Allmere, J. Näslund, A. Andrén, and A. Lundén. 2007. Effect of genetic polymophism of milk proteins on rheology of chymosin-induced milk gels. Int. Dairy J. 17:791-799.

Henno, M., M. Ots, I. Joudu, T. Kaart, and O. Kärt. 2008. Factors affecting the freezing point stability of milk from individual cows. Int. Dairy J. 18:210-215.

Ikonen, T., S. Morri, A.-M. Tyrisevä, O. Ruottinen, and M. Ojala. 2004 Genetic and phenotypic correlations between milk coagulation properties, milk production traits, somatic cell count, casein content, and pH of milk. J. Dairy Sci. 87:458-467.

International Committee for Animal Recording. 2008. Yearly Milk Enquiry Statistics. International Committee for Animal Recording, Rome, Italy.
King, R. L. 1962. Oxidation of milk fat globule membrane material. I. Thiobarbituric acid reaction as a measure of oxidized flavor in milk and model systems. J. Dairy Sci. 45:1165-1171.

Klei, L. R., J. M. Luynch, D. M. Barbano, P. A. Oltenacu, A. J Lednor, and D. K. Bandler. 1997. Influence of milking three times a day on milk quality. J. Dairy Sci. 80:427-436.

Lindmark Månsson, H., and B. Åkesson. 2000. Antioxidative factors in milk. Br. J. Nutr. 84:103-110.

Lindmark Månsson, H., R. Fondén, and H.-E. Pettersson. 2003. Composition of Swedish dairy milk. Int. Dairy J. 13:409-425.

Lindqvist, B., T. Roos, and H. Fujiuta. 1975. Zur Bestimmung freier Fettsäuren in Rohmilch mit dem Auto-Analyzer. Modifikation enier vorhandenden Methode zur Vereinfachung des Probentransporten. Milchwissenschaft 30:441.

Näslund, J., W. F. Fikse, G. R. Pielberg, and A. Lundén. 2008 Frequency and effect of the bovine acyl-CoA:diacylglycerol acyltransferase 1 (DGAT1) K232A polymorphism in Swedish dairy cattle. J. Dairy Sci. 91:2127-2134.

Nourooz-Zadeh, J., J. Tajaddini-Sarmadi, I. Birlouez-Aragon, and S. P. Wolff. 1995. Measurement of hydroperoxides in edible oils using ferrous oxidation in xylenol orange assay. J. Agric. Food Chem. 43:17-21.

O'Brien, B., T. Lennartsson, R. Mehra, T. M. Cogan, J. F. Connolly, P. A. Morrissey, and D. Harrington. 1999a. Seasonal variation in the composition of Irish manufacturing and retails milks. 3. Vitamins. Ir. J. Agric. Food Res. 38:75-85.

O'Brien, B.. R. Mehra, J. F. Connolly, and D. Harrington. 1999b. Seasonal variation in the composition of Irish manufacturing and retails milks. 1. Chemical composition and renneting properties. Ir. J. Agric. Food Res. 38:53-64.

O'Brien, B., R. Mehra, J. F. Connolly, and D. Harrington. 1999c Seasonal variation in the composition of Irish manufacturing and retails milks. 4. Minerals and trace elements. Ir. J. Agric. Food Res. 38:87-99.

Östdal, H., H. J. Andersen, and J. H. Nielsen. 2000. Antioxidative activity of urate in bovine milk. J. Agric. Food Chem. 48:55885592

Österman, S., K. Östensson, K. Svennerstein-Sjaunja, and J. Bertilsson. 2005. How does extended lactation in combination with different milking frequencies affect somatic cell counts in dairy cows? Livest. Prod. Sci. 96:225-232.

Pinto, C. M., R. E. Carrasco, L. B. Fraser, H. A. Letelier, and P. W. Dörner. 1998. Composition of raw milk and its variation in bulk milk in dairy factories in the VIII, IX and X regions of Chile. Agro Sur 26:97-109. (in Spanish).

Schennink, A., J. M. L. Heck, H. Bovenhuis, M. H. P. W. Visker, H. J. F. van Valenberg, and J. A. M. van Arendonk. 2008. Milk fatty acid unsaturation: Genetic parameters and effects of stearoyl-CoA desaturase $(S C D 1)$ and acyl CoA:diacylglycerol acyltransferase 1 (DGAT1). J. Dairy Sci. 91:2135-2143.

Schennink, A., W. M. Stoop, M. H. P. W. Visker, J. M. L. Heck, H. Bovenhuis, J. J. van der Poel, H. J. F. van Valenberg, and J. A M. van Arendonk. 2007. DGAT1 underlies large genetic variation in milk-fat composition of dairy cows. Anim. Genet. 38:467-473.

Shantha, N. C., and E. A. Decker. 1994. Rapid, sensitive, iron-based spectrophotometric methods for determination of peroxide values of food lipids. J. AOAC Int. 77:421-424.

Shipe, W. F., G. F. Senyk, and K. B. Fountain. 1980. Modified copper soap solvent-extraction method for measuring free fatty acids in milk. J. Dairy Sci. 63:193-198.

Slaghuis, B. A. 2001. The freezing point of authentic and original farm bulk tank milk in The Netherlands. Int. Dairy J. 11:121-126.

Smit, L. E., N. Smith, H. C. Schönfeldt, and P. H. Heinze. 1998. The nutritional content of South African milk and liquid milk products. Dairy Industry Centre, ARC-Animal Nutrition and Animal Science Institute, Irene, Republic of South Africa.

Soyeurt, H., and N. Gengler. 2008. Genetic variablity of fatty acids in bovine milk. Biotechnol. Agron. Soc. Environ. 12:203-210.

Stoop, M., H. Bovenhuis, and J. van Arendonk. 2006. Genetic and herd effects on milk composition in Dutch Holstein-Friesian primiparous cows. Poster at 3rd International Symposium Milk Genomics and 
Human Health, Brussels, Belgium. http://www.zod.wau.nl/abgorg/mgi/docs/science/posterStoopMGHH2006.pdf Accessed Oct. $12,2008$.

Stoop, W. M., H. Bovenhuis, and J. A. M. van Arendonk. 2007. Genetic parameters for milk urea nitrogen in relation to milk production traits. J. Dairy Sci. 90:1981-1986.

Stoop, W. M., J. A. M. van Arendonk, J. M. L. Heck, H. J. F. van Valenberg, and H. Bovenhuis. 2008. Genetic parameters for major milk fatty acids and milk production traits of Dutch Holsteinfriesians. J. Dairy Sci. 91:385-394.

Swedish Dairy Association. 2007. Dairy Statistics. Swedish Dairy Association, Stockholm, Sweden.

Swedish Dairy Association. 2008. Cattle Statistics. Swedish Dairy Association, Stockholm, Sweden.

Tuckey, S. L., and J. Stadhouders. 1967. Increase in sensitivity of organoleptic detection of lipolysis in cow's milk by culturing or direct acidification. Neth. Milk Dairy J. 21:158-162.

Tyrisevä, A.-M., T. Vahlsten, O. Ruottinen, and M. Ojala. 2004. Noncoagulation of milk in Finnish Ayrshire and Holstein-Friesian cows and effect of herds on milk coagulation ability. J. Dairy Sci. $87: 3958-3966$.

VikingGenetics. 2006. Avelsvärdering version VII. VikingGenetics, Skara, Sweden.
VikingGenetics. 2008. Avelsvärdering. VikingGenetics, Skara, Sweden. http://www.sweebv.info/ba52welcome.aspx Accessed Dec. 5, 2008.

Walstra, P., T. J. Geurts, A. Noomen, A. Jellema, and M. A. J. S. van Boekel, ed. 1999. Dairy Technology: Principles of Milk Properties and Processes. Marcel Dekker Inc., New York, NY.

Walstra, P., and R. Jenness. 1984. Dairy Chemistry and Physics. John Wiley and Sons Inc., Hoboken, NJ.

Wedholm, A., E. Hallén, L. B. Larsen, H. Lindmark Månsson, A. H. Karlsson, and T. Allmere. 2006a. Comparison of milk protein composition in a Swedish and a Danish dairy herd using reversed phase HPLC. Acta Agric. Scand., Sect. A 56:8-15.

Wedholm, A., L. B. Larsen, H. Lindmark Månsson, A. H. Karlsson, and A. Andrén. 2006b. Effect of protein composition and the cheese-making properties of milk from individual dairy cows. J. Dairy Sci. 89:3296-3305.

Wiking, L., J. H. Nielsen, A.-K. Båvius, A. Edvardsson, and K. Svennerstein-Sjaunja. 2006. Impact of milking frequencies on the level of free fatty acids in milk, fat globule size, and fatty acid composition. J. Dairy Sci. 89:1004-1009. 